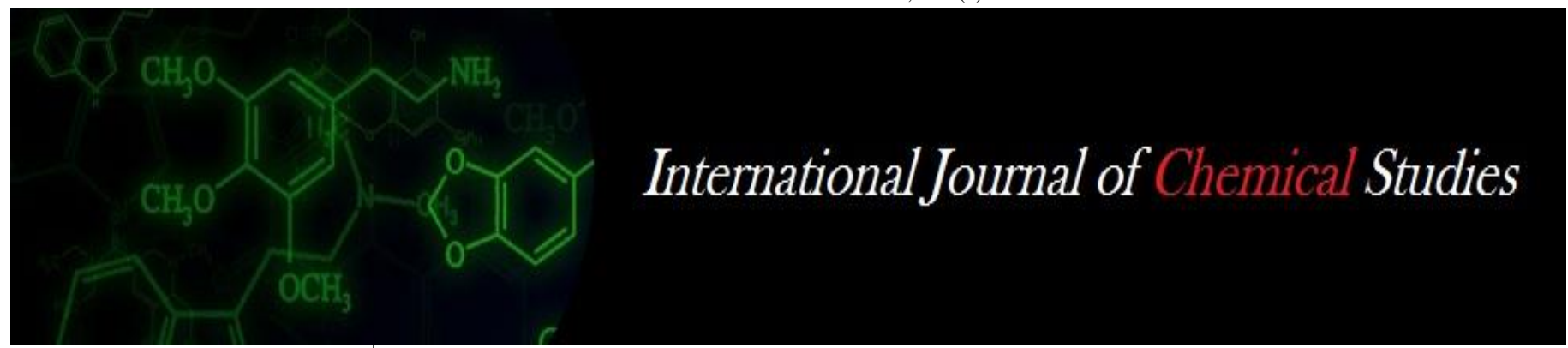

P-ISSN: 2349-8528

E-ISSN: 2321-4902

www.chemijournal.com

IJCS 2021; SP-9(1): 279-283

(C) 2021 IJCS

Received: 16-11-2020

Accepted: 30-12-2020

Kaparthi Bhanu Teja

Department of Dairy Chemistry,

Dairy Science College,

Karnataka Veterinary Animal

and Fisheries Sciences

University's Regional Campus,

Bengaluru, Karnataka, India

Jayashiri P Hiremath

Department of Dairy Chemistry,

Dairy Science College,

Karnataka Veterinary Animal

and Fisheries Sciences

University's Regional Campus,

Bengaluru, Karnataka, India
Corresponding Author: Kaparthi Bhanu Teja

Department of Dairy Chemistry,

Dairy Science College,

Karnataka Veterinary Animal

and Fisheries Sciences

University's Regional Campus,

Bengaluru, Karnataka, India

\section{Evaluation of quality attributes of flavoured goat milk incorporated with microencapsulated vitamin-C}

\author{
Kaparthi Bhanu Teja and Jayashiri P Hiremath
}

DOI: https://doi.org/10.22271/chemi.2021.v9.i1e.11730

\begin{abstract}
Goat milk has received much attention due to its better nutritional and therapeutic properties. However, its flavor limits its use by the consumers. To increase its acceptability flavoured goat milk was developed. Vitamin-C microcapsules were prepared using $3 \%$ sodium alginate and $0.2 \mathrm{M} \mathrm{CaCl} \mathrm{Cl}_{2}$ through extrusion process. Encapsulated vitamin-C enriched flavoured goat milk prepared by using $8 \%$ sugar, $0.75 \%$ Pista flavour was adjudged the best on 9-point hedonic scale. The physico-chemical, sensory and microbiological attributes of the flavored goat milk were determined. The prepared encapsulated vitamin$\mathrm{C}$ enriched flavoured goat milk showed specific gravity, viscosity, vitamin- $\mathrm{C}$, fat, protein, ash, total carbohydrate, total solids \& titratable acidity of $1.032,2.36 \mathrm{cP}, 33 \mathrm{mg} \%, 3.61 \%, 4.25 \%, 0.89 \%, 11.5 \%$, $20.25 \% \& 0.14 \%$ lactic acid respectively. The total bacterial, yeast and mould count were within limits of legal standard till $6^{\text {th }}$ day at storage temperature at $5 \pm 1^{\circ} \mathrm{C}$ fit for consumption.
\end{abstract}

Keywords: Goat milk, microencapsulation, flavoured milk, vitamin-C, encapsulation efficiency

\section{Introduction}

Milk can be considered a source of macro- and micronutrients, and also contains a number of active compounds that play a significant role in both nutrition and health protection. There are twenty well defined breeds of goats in India, although $70 \%$ population are non-descript and meat type. Some of the breeds such as Jamunapari, Barbari, Beetal, Surti, Jakhrana produce fairly good amount of milk [1]. Today, goat milk is of particular interest due to its specific composition, which has led to it being considered a high-quality raw material for manufacturing food for infants and the elderly, as well as for certain sectors of the population with particular needs. Global worth of goat milk and product in 2018 was 8 billion US dollar and it is estimated to hike about 15 billion dollars in 2024 with a growth rate of $10 \%$ [2]. The fatty acids caproic, caprylic, capric named after goat cause goaty flavour in goat milk because of their predominance ${ }^{[3]}$. Goat milk has about $1.5-2 \mathrm{mg} \%$ of vitamin $\mathrm{C}$. The average size of goat milk fat globules is about $3.5 \mu \mathrm{m}$ as compared to $4.5 \mu \mathrm{m}$ for cow milk fat hence it is called naturally homogenized milk ${ }^{[4]}$. Further, goat milk as such is not preferred by consumers because of its unacceptable caprine flavour. So, preparation of flavoured goat milk can improve the acceptability, palatability and render its health benefits to the consumers. Microencapsulation has numerous applications in areas such as the pharmaceutical, agricultural, Medical and food industries, being widely used in the encapsulation of essential oils, colours, flavours, sweeteners, microorganisms, vitamins, among others ${ }^{[5]}$. It has been used to improve the stability of ascorbic acid. Encapsulation of ascorbic acid as a functional dietary ingredient has drawn more attention in recent years (Desai et al., 2005) ${ }^{[6]}$. The known instability of free ascorbic acid requires establishing stable forms that protect the encapsulated compounds from factors such as heat and humidity, thus improving their stability and bioavailability. There is a barrier protection against oxygen, water, and light, avoiding contact with other particles or ingredients (Mortazavian et al., 2007) ${ }^{[7]}$. Alginate hydrogels are extensively used in cell encapsulation and calcium alginate is preferred for encapsulating because of its simplicity, non- toxicity, biocompatibility and low cost. FDA has granted the generally recognized as safe (GRAS) status to alginates (Rowley et al., 1999) ${ }^{[8]}$. 
From economic point of view flavoured milks are important because it makes milk more palatable to those who don't relish goat milk as such. Flavoured milk is one of the good vehicles for supplying milk constituents to the milk consumption world and survives an ambient condition. Keeping these in view, the present investigation to develop flavoured goat milk enriched with encapsulated vitamin $\mathrm{C}$ was carried out and the sensory and physico-chemical and keeping quality of the product were explored.

\section{Materials and Methods \\ Materials}

Fresh raw goat milk was procured from (Basta goat milk) Vistara Farm Pvt. Ltd, Kengeri Bengaluru, Pista flavour was procured from Sheriff unani \& Ayurvedic pharma, Excelsior plaza, Bangalore-01, Calcium chloride of food grade was procured from Nandu Chemical industries, N- 12, Industrial Estate, Hubli, Food grade Sodium alginate (E401) manufactured by Urban Platter, Mumbai-16, and L-Ascorbic acid of food grade manufactured by I and Z essentials. LBS Marg, Mumbai procured from online shopping

Optimization of levels of sodium alginate and calcium chloride for formation of alginate beads

It was carried out as per the methods of Thangaraj and Seethalakshmi (2015) ${ }^{[9]}$.

Encapsulation Efficiency of vitamin-C encapsulated beads Encapsulation efficiency of vitamin- $\mathrm{C}$ content was estimated by 2,6 dichloro phenol indophenol titrimetric method as described in the AOAC $1980^{[10]}$.

\section{Preparation of encapsulated vitamin-C incorporated} flavoured goat milk

The filtered goat milk was preheated to $40^{\circ} \mathrm{C}$. The sugar levels tried were $7,8,9$ per cent and pista flavour at $0.5,0.75$ and 1 per cent. Calculated amount of microencapsulated vitamin-C was added based on recommended dietary allowance (RDA) for children and adult's microcapsule containing $40 \mathrm{mg}$ per cent of vitamin- $\mathrm{C}$ were added in $100 \mathrm{ml}$ flavoured milk and free vitamin-C of $40 \mathrm{mg}$ per cent was incorporated to $100 \mathrm{ml}$ flavoured milk, as this led to flakes formation upon heating. Maximum quantity that prevented flakes formation was used i.e., $6.5 \mathrm{mg}$ per cent in free vitamin-C incorporated flavoured goat milk and Encapsulation efficiency (EE) was also calculated. The sample was pasteurized at $72^{\circ} \mathrm{C}$ for $15 \mathrm{secs}$ and cooled rapidly to $5^{\circ} \mathrm{C}$. As, goat milk is not susceptible sterilization temperature. So, pasteurization was only done. Sensory attributes of encapsulated vitamin-C incorporated flavoured goat milk was evaluated on 9-point Hedonic scale by a panel of 5 judges.

\section{Sample details}

Control: Encapsulated vitamin-C incorporated flavoured cow milk, B1: Encapsulated vitamin-C incorporated flavoured goat milk, B2: Free vitamin C incorporated flavoured goat milk

\section{Physico-chemical analysis}

The Specific gravity, viscosity, fat, protein, total solids, titratable acidity, total carbohydrate in the sample was determined as per method described in (IS: SP:18: Part XI, 1981) ${ }^{[10]}$. The total ash and vitamin-C was determined by following the method as per method in ${ }^{[11]}$.

\section{Microbiological analysis}

The total bacterial count, coliforms and yeast and mold count of control and experimental samples was determined by following the procedure of ${ }^{[12]}$.

\section{Results and Discussion}

Table 1: Optimization of levels of sodium alginate and calcium chloride for formation of alginate beads

\begin{tabular}{|c|c|c|c|}
\hline \multirow{2}{*}{$\begin{array}{c}\text { Calcium chloride } \\
\text { solution (M) }\end{array}$} & \multicolumn{3}{|c|}{ Sodium alginate \% } \\
\cline { 2 - 4 } & $\mathbf{1}$ & $\mathbf{2}$ & $\mathbf{3}$ \\
\hline 0.10 & - & + & ++ \\
\hline 0.15 & - & ++ & +++ \\
\hline 0.20 & - & ++ & +++ \\
\hline
\end{tabular}

- No beads formed + Loose beads ++ Soft textured beads +++ Rigid textured beads

Optimization process of 1 percent sodium alginate powder showed no bead (microcapsule) formation, with 2 per cent sodium alginate in $0.2 \mathrm{M} \mathrm{CaCl}_{2}$ was observed soft texture of beads but with 3 per cent sodium alginate in $0.2 \mathrm{M} \mathrm{CaCl}_{2}$, the beads were rigid and soft body. Hence, it was better to develop the beads for encapsulation of vitamin-C.

Table 2: Encapsulation Efficiency (\%) of vitamin-C on optimized encapsulated beads

\begin{tabular}{|c|c|c|c|c|c|}
\hline \multirow{2}{*}{$\begin{array}{c}\text { Encapsulation } \\
\text { Efficiency \% }\end{array}$} & \multicolumn{5}{|c|}{ Vitamin - C (mg) } \\
\cline { 2 - 6 } & $\mathbf{1 0 0}$ & $\mathbf{2 0 0}$ & $\mathbf{3 0 0}$ & $\mathbf{4 0 0}$ & $\mathbf{5 0 0}$ \\
\cline { 2 - 6 } & 80 & 70.6 & 65.8 & 62.2 & 59.4 \\
\hline
\end{tabular}

Table 3: Sensory attributes of Optimized Flavoured goat milk incorporated with microencapsulated vitamin-C

\begin{tabular}{|c|c|c|c|c|}
\hline Type of sample & $\begin{array}{c}\text { Colour \& } \\
\text { appearance }\end{array}$ & $\begin{array}{c}\text { Body \& } \\
\text { texture }\end{array}$ & Flavour & $\begin{array}{c}\text { Overall } \\
\text { acceptability }\end{array}$ \\
\hline Control & $7.83^{\mathrm{a}}$ & $7.81^{\mathrm{a}}$ & $8.16^{\mathrm{a}}$ & $8.13^{\mathrm{a}}$ \\
\hline $\mathrm{B} 1$ & $7.93^{\mathrm{a}}$ & $7.83^{\mathrm{a}}$ & $8.20^{\mathrm{a}}$ & $8.20^{\mathrm{a}}$ \\
\hline $\mathrm{B} 2$ & $8.32^{\mathrm{b}}$ & $8.26^{\mathrm{b}}$ & $8.10^{\mathrm{a}}$ & $8.36^{\mathrm{a}}$ \\
\hline CD $(P=.05)$ & 0.27 & 0.34 & 0.72 & 0.33 \\
\hline
\end{tabular}

Control: Encapsulated vitamin-C incorporated flavoured cow milk

B1: Encapsulated vitamin-C incorporated flavoured goat milk

B2: Free vitamin $\mathrm{C}$ incorporated flavoured goat milk

\section{Different superscripts indicate significant difference}

From the table 3 , it is clear that the sensory scores secured for control and flavoured goat milk with added beads were decreased compared to the sensory scores obtained for free vitamin-C incorporated flavoured goat milk. This indicates its effect on colour and appearance of encapsulates treated product. Similar observations were reported by Thangaraj and Seethalakshmi (2015) ${ }^{[9]}$ who evaluated encapsulated vitamin$\mathrm{C}$ enriched flavoured milk and found that colour and appearance score of control and sample scored 7.5 and 7.3 respectively.

The incorporation of encapsulated beads to goat milk to prepare encapsulated vitamin-C incorporated flavoured goat milk resulted in decreased body and texture scores compared to free vitamin-C incorporated flavoured goat milk as free vitamin-C dissolved in the goat milk. However, it indicated that incorporation of encapsulated vitamin-C beads in flavoured goat milk showed homogeneous distribution without causing any adverse effects.

The flavour score for the control and the experimental flavoured goat milk samples had no impact. Since alginate is a polysaccharide, it does not contribute to flavour. Similar 
observations were reported by Chitra et al. (2015) ${ }^{[13]}$ who evaluated the sensory characteristics and oxidative stability of fortified milk and reported that from the first to the fifth day and reported that the sensory scores of iron salt fortified milk were significantly lower as compared with milk fortified with microencapsulated iron control and sample scored 9.2 and 8.3 respectively.

The maximum overall acceptability score was awarded to encapsulated vitamin-C incorporated flavoured goat milk, which had comparatively similar score for colour and appearance, body and texture and flavour compared to the control. Encapsulated vitamin-C incorporated flavoured goat milk showed slightly lesser score compared to free vitamin-C incorporated flavoured goat milk. Similar reports were made by Mousa et al. (2014) ${ }^{[14]}$ who studied sensory property for creamier yogurt incorporated with alginate beads and found overall acceptability of the control treatment differed significantly in comparison with the treatments of free cells and double-layer microcapsules 6.6, 7.0 and 6.8 respectively. Lee et al. (2004) ${ }^{[15]}$ reported that L-ascorbic acid microencapsulated with polyacylglycerol monostearate for milk fortification showed no differences for most sensory aspects between control and microencapsulated groups and the sensory test was conducted on commercial whole milk containing encapsulated L-ascorbic acid (0,100 and $250 \mathrm{ppm})$ that had been stored at $4^{\circ} \mathrm{C}$ for $1,3,5,8$ or $12 \mathrm{~d}$. The intensity of off-flavor and sourness were scored on a 5-point scale and results scored between 1 and 3 during storage.

Table 4: Physico-chemical characteristics of the optimized encapsulated vitamin-C enriched flavoured goat milk

\begin{tabular}{|c|c|c|c|c|c|c|c|c|c|}
\hline Type of samples & Specific gravity & Viscosity (cP) & $\begin{array}{c}\text { Vitamin-C } \\
(\mathbf{M g} \%)\end{array}$ & Fat (\%) & Protein (\%) & Ash & $\begin{array}{c}\text { Total } \\
\text { Carbohydrate (\%) }\end{array}$ & $\begin{array}{c}\text { Total } \\
\text { Solids (\%) })\end{array}$ & $\begin{array}{c}\text { Titratable } \\
\text { acidity (\%LA) }\end{array}$ \\
\hline Control & $1.031^{\mathrm{a}}$ & $2.10^{\mathrm{a}}$ & $34.0^{\mathrm{a}}$ & $3.28^{\mathrm{a}}$ & $3.62^{\mathrm{a}}$ & $0.78^{\mathrm{a}}$ & $12.1^{\mathrm{a}}$ & $19.78^{\mathrm{a}}$ & $0.141^{\mathrm{a}}$ \\
\hline $\mathrm{B} 1$ & $1.032^{\mathrm{a}}$ & $2.36^{\mathrm{b}}$ & $33.0^{\mathrm{b}}$ & $3.61^{\mathrm{b}}$ & $4.25^{\mathrm{b}}$ & $0.89^{\mathrm{b}}$ & $11.5^{\mathrm{b}}$ & $20.25^{\mathrm{b}}$ & $0.143^{\mathrm{a}}$ \\
\hline $\mathrm{B} 2$ & $1.030^{\mathrm{a}}$ & $1.91^{\mathrm{c}}$ & $4.1^{\mathrm{c}}$ & $3.59^{\mathrm{b}}$ & $4.24^{\mathrm{b}}$ & $0.83^{\mathrm{c}}$ & $11.4^{\mathrm{b}}$ & $20.06^{\mathrm{c}}$ & $0.161^{\mathrm{b}}$ \\
\hline $\mathrm{CD}(P=.05)$ & 0.004 & 0.17 & 0.15 & 0.13 & 0.04 & 0.035 & 0.32 & 0.03 & 0.006 \\
\hline
\end{tabular}

Control: Encapsulated vitamin-C incorporated flavoured cow milk

B1: Encapsulated vitamin-C incorporated flavoured goat milk

B2: Free vitamin $\mathrm{C}$ incorporated flavoured goat milk

\section{Different superscripts indicate significant difference}

From the table4, it is clear that the specific gravity for control was lower than the recorded for experimental flavoured goat milk with microencapsulated vitamin $C$. However, there was no significant $(P=.05)$ difference between the control and experimental flavoured goat milk samples. This is in accordance with the reports of [16], who clearly reported that the specific gravity of different low-calorie herbal flavoured milk ranges between 1.03 to 1.058 .

As regards viscosity, it was highest $(2.36 \mathrm{cP})$ in case of B1 compared to the other samples. Statistical analysis showed that there was significant $(P=.05)$ difference between the control and experimental flavoured goat milk samples [17]. Reported the rheological properties of ice cream had greater viscosity possibly due to the addition of encapsules aggregates.

It is clear from table 4 that maximum vitamin- $\mathrm{C}$ was observed in control flavoured milk viz., $34 \mathrm{mg}$ per cent as compared to the encapsulated vitamin-C incorporated flavoured goat milk. The statistical analysis showed that there was significant $(P$ $=.05$ ) difference between the control and experimental flavoured goat milk samples. These findings are in agreement with the findings of [9] in production of vitamin-C encapsulated flavoured milk sample and found that the sample retained $355 \mathrm{mg}$ per cent of vitamin-C upon incorporation of $500 \mathrm{mg}$ per cent.

It was observed that the fat content was significantly higher in case of the experimental flavored goat milk compared to control which may be due to higher content of fat in the goat milk used for preparation compared to cow milk Similar findings with respect to average fat contents of control flavoured milk (CFM) and palmyrah fruit pulp flavoured milk toned with soy milk (PFM) was 3.93 and 3.0 per cent fat respectively reported by ${ }^{[18]}$.

Fat content was higher in encapsulated vitamin-C incorporated flavoured goat milk (4.25 per cent) and free vitamin-C incorporated flavoured goat milk (4.24 per cent) as against control sample (3.62 per cent). The content of protein was significantly high in case of the flavoured goat milk compared to control this may be ascribed to the higher protein content in the goat milk compared to the cow milk. Similar observations of higher protein contents 3.44 to 3.70 per cent were reported in fruit flavoured milk-based beverages by ${ }^{[19]}$.

The content of ash for control was 0.78 per cent whereas for encapsulated vitamin-C incorporated flavoured goat milk and free vitamin-C incorporated flavoured goat milk was 0.89 and 0.83 per cent respectively. There was a significant $(P=.05)$ difference between the control and experimental flavoured goat milk samples. The higher ash content may be due to the calcium alginate that formed during microencapsulation of vitamin C. This is in accordance with the reports of ${ }^{[20]}$ in case of flavoured milk added with Piper betel leaves recorded ash content of 0.90 per cent.

It was observed that the total carbohydrate content for control was 12.1 per cent whereas for encapsulated vitamin-C incorporated flavoured goat milk and free vitamin-C incorporated flavoured goat milk was 11.5 and 11.4 per cent respectively. There was a significant difference between control and flavoured goat milk. As goat milk has lower lactose content compared to cow milk, a lower total carbohydrate content was found in case of experimental flavoured milk. These findings are in agreement with the findings of ${ }^{[20]}$ in production of flavoured cow milk added with Piper betel leaves and found that the sample contain 13.64 per cent of total carbohydrate upon incorporation 9 per cent sugar From the (Table 4) it is also evident that the total solid content for control and free vitamin-C incorporated flavoured goat milk were 19.78 and 20.06 per cent respectively as the milk used had a higher total solids content. Total solids content was significantly $(P=.05)$ higher in the experimental flavoured milk. The results are also in corroborative with the reports of ${ }^{[21]}$ who reported that of total solid contents in flavoured milk from cow milk blended with safflower milk were 15.21 per cent in control.

The titratable acidity (\% LA) recorded for encapsulated vitamin-C incorporated flavoured goat milk and free vitamin$\mathrm{C}$ incorporated flavoured goat milk were 0.14 and $0.16 \%$ LA respectively as against control $(0.14 \%$ LA). The values were 
nonsignificant for encapsulated vitamin $\mathrm{C}$ enriched flavoured goat milk. Maximum acidity was observed in free vitamin-C incorporated flavoured goat milk i.e., $0.16 \%$ LA as compared to the encapsulated vitamin-C incorporated flavoured goat milk. These values of present investigation are comparable with value reported by Balasaheb et al. (2017) ${ }^{[22]}$ in case of flavoured milk blended with jackfruit pulp recorded titratable acidity ranged from 0.15 to $0.17 \% \mathrm{LA}$.

\section{Microbiological analysis}

Table 5: Total bacterial count in optimized encapsulated vitamin-C enriched flavoured goat milk during storage $\left(5 \pm 1^{\circ} \mathrm{C}\right)$

\begin{tabular}{|c|c|c|c|c|c|}
\hline \multirow{2}{*}{ Type of Sample } & \multicolumn{5}{|c|}{ Total bacterial count (log10 cfu/ml) } \\
\cline { 2 - 5 } & \multicolumn{5}{|c|}{ Storage period (days) } \\
\cline { 2 - 5 } & $\mathbf{0}$ & $\mathbf{2}$ & $\mathbf{4}$ & $\mathbf{6}$ & \multirow{2}{*}{ Spoiled } \\
\hline Control & $3.04^{\mathrm{a}}$ & $3.17^{\mathrm{a}}$ & $3.28^{\mathrm{a}}$ & $4.49^{\mathrm{a}}$ & \\
\hline $\mathrm{B} 1$ & $3.07^{\mathrm{a}}$ & $3.20^{\mathrm{a}}$ & $3.31^{\mathrm{a}}$ & $4.53^{\mathrm{a}}$ & \\
\hline $\mathrm{B} 2$ & $3.25^{\mathrm{b}}$ & $3.53^{\mathrm{b}}$ & $3.57^{\mathrm{b}}$ & $4.60^{\mathrm{b}}$ & \\
\hline CD $(P=.05)$ & 0.03 & 0.04 & 0.03 & 0.04 & \\
\hline
\end{tabular}

Control: Encapsulated vitamin-C incorporated flavoured cow milk

B1: Encapsulated vitamin-C incorporated flavoured goat milk

B2: Free vitamin $\mathrm{C}$ incorporated flavoured goat milk

\section{Different superscripts indicate significant difference}

The total plate count increased gradually during storage of all types of flavoured milk at $\left(5 \pm 1^{\circ} \mathrm{C}\right)$. At the $8^{\text {th }}$ day $4.49,4.53$ and $4.60 \log _{10} \mathrm{cfu} / \mathrm{ml}$ in control, B1 and B2 flavoured milk. In control, the total bacterial plate count was lesser than the experimental flavoured milk samples. The control and other experimental samples were found to be spoiled on 8th day of storage as the total bacterial count exceeded the limits of standard microbial count. These results are also in relevance with the findings of ${ }^{[23]}$ who reported that the total plate count from pasteurized flavoured milk samples from different companies were in the range of 2.3 to $6.3 \log _{10} \mathrm{cfu} / \mathrm{ml}$ stored at $5 \pm 1^{\circ} \mathrm{C}$ for 7 days. This indicated the fulfillment of the legal requirements of quality standards of flavoured milk (FSSR, 2017) [24] till 6th day of storage. Hence, the optimized encapsulated vitamin-C enriched flavoured goat milk samples stored at $5 \pm 1^{\circ} \mathrm{C}$ is safe for consumption only up to 6 days.

Table 6: Coliform, Yeast \& mold count in optimized encapsulated vitamin-C enriched flavoured goat milk during storage $\left(5 \pm 1^{\circ} \mathrm{C}\right)$

\begin{tabular}{|c|c|c|c|c|c|c|}
\hline $\begin{array}{c}\text { Storage } \\
\text { period } \\
\text { (days) }\end{array}$ & Coliform & $\begin{array}{c}\text { Ceast \& } \\
\text { mold }\end{array}$ & Coliform & $\begin{array}{c}\text { Yeast \& } \\
\text { mold }\end{array}$ & Coliform & $\begin{array}{c}\text { Yeast \& } \\
\text { mold }\end{array}$ \\
\hline \multicolumn{7}{|c|}{$\log _{10}$ cfu/ml } \\
\hline 0 & Nil & Nil & Nil & Nil & Nil & Nil \\
\hline 2 & Nil & Nil & Nil & Nil & Nil & Nil \\
\hline 4 & Nil & Nil & Nil & Nil & Nil & Nil \\
\hline 6 & Nil & Nil & Nil & Nil & Nil & Nil \\
\hline 8 & Nil & 2.36 & Nil & 1.95 & Nil & 2.0 \\
\hline
\end{tabular}

Control: Encapsulated vitamin-C incorporated flavoured cow milk

B1: Encapsulated vitamin-C incorporated flavoured goat milk

B2: Free vitamin $\mathrm{C}$ incorporated flavoured goat milk

\section{Different superscripts indicate significant difference}

The coliform count was nil throughout the storage period which indicates the hygienic practices followed throughout the study. The yeast and mold count were nil in control, encapsulated vitamin-C incorporated flavoured goat milk and free vitamin-C incorporated flavoured goat milk up to $6^{\text {th }}$ day of storage but on $8^{\text {th }}$ day, all the samples showed yeast $\&$ mold growth. On the $8^{\text {th }}$ day of storage control and experimental samples showed 2.36, 1.95 and $2.0 \log _{10} \mathrm{cfu} / \mathrm{ml}$ of yeast and mold growth respectively probably due to the increased titratable acidity during storage which favored the growth. Hence it can be concluded that the optimized encapsulated vitamin- $\mathrm{C}$ incorporated flavoured goat milk samples stored at $5 \pm 1{ }^{\circ} \mathrm{C}$ is safe for consumption only up to 6 days. The results obtained in the present investigation are comparable with the results reported by ${ }^{[25]}$ where no added sugar ready to drink milk supplemented with mango pulp stored at $4 \pm 1{ }^{\circ} \mathrm{C}$ for a period of 10 days showed $1.48 \log _{10}$ $\mathrm{cfu} / \mathrm{ml}$ yeast and mold count on $6^{\text {th }}$ day of the storage period.

\section{Conclusion}

Flavoured goat milk was prepared by using microcapsules of $3 \%$ sodium alginate and $0.2 \mathrm{M}$ Calcium chloride levels. Level of addition of vitamin-C was optimized based on encapsulation efficiency, beads with $80 \%$ Encapsulation efficiency were used. Encapsulated vitamin-C enriched flavoured goat milk was prepared by utilizing $8 \%$ sugar, $0.75 \%$ pista flavour was adjudged the finest. Encapsulated vitamin-C enriched flavoured goat milk retained $29.6 \mathrm{mg}$ of vitamin-C up to 6 days

\section{References}

1. Rashmi A, Bhojak N, Rajani J. Comparative aspect of goat and cow milk. International Journal of Engineering Sciences and Inventions 2013;2(1):7-10.

2. Food and agricultural organization of united nations (FAO). Statistical databases 2019.

3. Ceballos L, Morales E, De La Torre Adarve G, Diaz castro J, Martinez L, Remedios S. Composition of goat and cow milk produced under similar conditions and analyzed by identical methodology. Journal of Food Composition Analysis 2009;22:322-329.

4. National Dairy Development Board (NDDB). Goat Milk: composition \& processing technology 2018;9:1-3.

5. Azeredo. Encapsulation: Application to food technology. International Journal of Dairy science 2005;20:346-348.

6. Mortazavian A, Razavi SH, Ehsani MR, Sohrabvandi S. Principles and methods of microencapsulation of probiotic microrganisms, Iranian. Journal of Biotehnology 2007;5(1):1-18.

7. Rowley JA, Madlambayan G, Mooney DJ. Alginate hydrogels as synthetic extracellular matrix materials. Biomaterials 1999;20(1):45-53.

8. Desai KGH, Liu C, Park HJ. Characteristics of vitamin C immobilized particles and sodium alginate beads containing immobilized particles. Journal of Microencapsulation 2005;22(4):363-376.

9. Thangaraj S, Seethalakshmi M. Application of microencapsulation technology for the production of Vitamin-C fortified flavoured milk. Journal of Advanced Dairy Research 2015;3(3):1-4.

10. IS: SP: 18 (Part XI). ISI Handbook of food analysis part XI Dairy Products, Indian Standards Institution New Delhi 1981, 62.

11. AOAC. Association of Official Analytical Chemists. $13^{\text {th }}$ Edn. Official method of analysis. Washington, D.C. USA 1980.

12. HARRIGAN. Laboratory methods in food and dairy microbiology, Dept. of Food Sci., Reading Univ., Reading Academy Press Inc (London) ltd, UK 1998.

13. Chitra Gupta, Prince Chawla, Sumit Arora. Development and evaluation of iron microencapsules for milk fortification. CyTA - Journal of Food 2015;13(1):116123. 
14. Mousa A, Liu XM, Chen YQ, Zhang H, Chen W. Evaluation of physiochemical textural, microbiological and sensory characteristics in set yogurt reinforced by microencapsulated Bifidobacterium bifidum F-35. International Journal of Dairy Technology 2014;49:16731679.

15. Lee JB, Ahn J, Lee J, Kwak HS. L-Ascorbic acid microencapsulated with polyacylglycerol monostearate for milk fortification. Bioscience Biotechnology Biochemistry 2004;68:495-500.

16. Pugazhenthi TR, Jothylingam S. Analysis of physico chemical properties of low calorie herbal flavoured milk. Tamil Nadu Journal of Veterinary \& Animal Science 2013;9(5):372-377.

17. Adapa S, Dingeldein H, Schmidt KA, Herald TJ. Rheological Properties of Ice Cream Mixes and Frozen Ice Creams Containing Fat and Fat Replacers. Journal of Dairy Science 2000;83(10):2224-2229.

18. Guberan G, Sarmini M, Silva KFST. Development of a Palmyrah (Borassus flabelifer) Fruit Pulp Flavored Pasteurized Milk Toned with Soy (Glycine max) Milk. International Journal of Livestock Research 2016;6(10):11-18.

19. Massarat Hassan, Basharat ND, Sajad A, Rather, Rehana Akhter, Aamina BH. Physico- chemical, sensory and microbial characteristics of fruit flavoured milk based beverages during refrigerated storage. Advances Biomedical Pharmacy 2015;2(1):32-39.

20. Vaibhav S, Kamble, Dnyaneshwar D, Patange, Dinakar $\mathrm{K}$, Kamble et al. Process Optimization for Flavoured Milk Added with Piper betel leaves. International journal of Current Microbiology and Applied Sciences 2019;8(1):713-724.

21. Repate KC, Kamble VJ, Hassan Bin Awaz, Thombre BM. Studies on preparation of flavoured milk from cow milk blended with safflower milk. Asian Journal of Dairy and Food Research 2010;29(2):92-96.

22. Balasaheb S, Poonam Naik, Joshi SV, Dandekar VS, Mayekar AJ. Chemical composition of flavoured milk blended with Jackfruit (Artocarpus heterophyllus L.) pulp. International Journal of Chemical Studies 2017;5(3):855-857.

23. Jubaida Binte J, Sharmin Akter, MD Aftab Uddin. Microbiological quality determination of pasteurized, UHT and flavoured milk sold in Dhaka, Bangladesh. Stamford Journal of Microbiology 2018;8(1):1-6.

24. Food safety and standards (food products standards and food additives) regulations. FSSAI, New Delhi, India 2017, 287-450.

25. Usha Bajwa, Shikha Mittal. Quality characteristics of no added sugar ready to drink milk supplemented with mango pulp. Journal of Food Science Technology 2015;52(4):2112-2120. 